\title{
Stem cells or their exosomes: which is preferred in COVID- 19 treatment?
}

\author{
Nashmin Fayazi Hosseini • Razieh Dalirfardouei • Mohammad Reza Aliramaei • \\ Rezvan Najafi (i)
}

Received: 30 January 2021 / Accepted: 4 November 2021 / Published online: 19 January 2022

(C) Springer Nature B.V. 2021

\begin{abstract}
It only took 8 months for the pneumonia caused by a previously unknown coronavirus to turn into a global pandemic of unprecedentedly far-reaching implications. Failure of the already discovered treatment measures opened up a new opportunity to evaluate the potentials of mesenchymal stem cells and their extracellular vesicles (EVs), exosomes in particular. Eventually, the initial success experienced after the use of MSCs in treating the new pneumonia by Lnge and his team backed up the idea of MSC-based therapies and pushed them closer to becoming a reality. However, MSC-related concerns regarding safety such as abnormal differentiation, spontaneous malignant and the formation of ectopic tissues have triggered the replacement of MSCs by their secreted exosomes. The issue has been further strengthened by the fact that the exosomes leave similar treatment impacts when compared to their parental cells. In recent years, much attention has been paid to the use of
\end{abstract}

N. F. Hosseini · R. Dalirfardouei · R. Najafi ( $₫)$ Research Center for Molecular Medicine, Hamadan University of Medical Sciences, Hamadan, Iran e-mail: re.najafi@umsha.ac.ir; najafi2535@gmail.com

R. Dalirfardouei

Endometrium and Endometriosis Research Center, Hamadan University of Medical Sciences, Hamadan, Iran

M. R. Aliramaei

Iranian Blood Transfusion Organization Center, Sanandaj, Iran
MSC-derived exosomes in the treatment of a variety of diseases. With a primary focus on COVID-19 and its current treatment methods, the present review looks into the potentials of MSCs and MSC-derived exosomes in battling the ongoing pandemic. Finally, the research will draw an analogy between exosomes and their parental cells, when it comes to the progresses and challenges in using exosomes as a large-scale treatment method.

Keywords Coronavirus - COVID-19 - Exosome based therapy $\cdot$ Mesenchymal stem cell-derived exosomes

\section{Introduction}

In February 2020, the World Health Organization (WHO) identified the coronavirus (SARS-CoV-2) as the responsible cause of the pandemic coronavirus disease 2019 (COVID-19) (McIntosh et al. 2020). Increase in the daily COVID-19-related deaths has made it the most important global issue. SARS-CoV-2 is the third type of pathogenic CoVs after two highly pathogenic $\mathrm{CoVs}$ named severe acute respiratory distress syndrome coronavirus (SARS-CoV-1) and the Middle East Respiratory Syndrome Coronavirus (MERS-CoV) first detected in Wuhan, China (Sahin et al. 2020). From the outbreak of coronavirus on 31 
December 2019 until 9 August 2021, there have been 202,296,216 confirmed cases of COVID-19 and 4,288,134 recorded deaths, which have been reported to WHO. The high spread rate [the basic reproduction number (R0) range: 3.8 to 8.9], the relatively long incubation period (7-14 days), and the lack of uniform symptoms across patients pushed the outbreak into the level of a global pandemic (Elrashdy et al. 2020).

A wide range of symptoms ranging from mild, common cold to severe and acute respiratory illness and consequent death have been reported in patients infected with SARS-CoV-2 (Singhal 2020). The coronavirus death rate was $3.4 \%$ of reported COVID-19 cases worldwide (Gaye et al. 2020). Age and pre-existing medical conditions (diabetes, hypertension, respiratory disease, and cardiovascular disease) ae believed to increase the death risk in patients infected by the virus (Aggarwal et al. 2020; Iaccarino et al. 2020).

Although several effective vaccines are now available to immunize individuals, a daily discovery of fresh facts about the structure, pathogenicity, transmission system, and immune properties of the SARSCoV-2 virus have made scientists around the world continue research into all possible treatment strategies to treat the infected populations.

\section{COVID-19 pathogenesis}

Coronavirus is a non-segmented positive singlestranded RNA (26-32 kb) virus enclosed by a spherical or pleomorphic envelope belonging to the family of Coronaviridae and the genus Coronavirus (De Haan et al. 1998). The virus is capable of entering and infecting human cells via two types of cell receptors, including the angiotensin-converting enzyme 2 (ACE2) receptor and the transmembrane serine protease 2 (TMPRSS2) (Hoffmann et al. 2020a; Zhou et al. 2020). The ACE2 receptor is the main cause of systemic diseases as it is widely distributed on the surface of many human cell types such as pulmonary, renal, cardiac, arteries, and intestines cells (Verma et al. 2020). Due to the high expression of both receptors in the alveolar type II (AT-II) cells, lungs are the major infected organ that are severely affected by the virus (Devaux et al. 2020).

Down-regulation of alveolar cell surface ACE2 after viral invasion alters the ACE/ACE2 balance toward ACE and promotes vascular inflammation and oxidative stress (Zhang et al. 2020a, b, c). Moreover, the recognition of the pathogen-associated molecular patterns (PAMPs) such as viral RNAs by various pattern recognition receptors (PRRs) including tolllike receptors (TLRs) 3, 7, 8, and 9, melanomadifferentiation-associated gene 5 (MDA5), cyclic GMP-AMP synthase (cGAS), and retinoic acid-inducible gene I (RIG-1) contribute to the production of high levels of IFN-I as the first innate immune response against viral infections and subsequently induces secretion inflammatory cytokines by activated cytotoxic CD8+ T cells and CD4+ T helper 1 (Th1) (Takeuchi and Akira 2009; Hoffmann et al. 2020a; Moore and June 2020).

This inflammatory microenvironment in the lungs with the extensive viral proliferation effectively raise the level of pro-inflammatory cytokines and chemokines including IFN- $\alpha$, interleukin-2 (IL-2), IL-6, IL-7, IL-12, granulocyte-colony stimulating factor (G$\mathrm{CSF}$ ), tumor necrosis factor-alpha (TNF $\alpha)$, interferon- $\gamma$-inducible protein 10 (IP-10), macrophage inflammatory protein-1 alpha (MIP-1A), transforming growth factor-beta (TGF- $\beta$ ), CCL2, CCL3, CCL5 and CXCL8 which have been repeatedly reported in those infected by COVID-19 patients (Wu et al. 2014; Taghavi-Farahabadi et al. 2020).

This life-threatening form of systemic inflammatory response that is called cytokine release syndrome (CRS) is responsible for symptoms such as pneumonia, acute respiratory distress syndrome (ARDS), and multi-organ failure in COVID-19 patients (Epelbaum 2020; Huang et al. 2020; Mehta et al. 2020; Moore and June 2020; Xu et al. 2020).

Among leading causes of death in patients, infected by SARS-CoV-2, including viral pneumonia, ARDS, septic shock, and heart disease, ARDS is the leading cause of death (Mehta et al. 2020). Based on such information, curbing and reducing inflammatory reactions is probably one reliable way to save COVID-19 patients.

\section{Current available treatments}

In this episode of coronavirus global emergency, the first medical strategy to fight against COVID-19 is use of off-labeled antibiotics and antiviral drugs to prevent the virus replication cycle and to inhibit host 
inflammation. This strategy mostly leads to supportive and symptomatic treatment and even promising results in some cases, but is not a definitive treatment for this infection. For instance, immunomodulatory interventions such as tocilizumab (a blocker of IL-6 receptor), adalimumab (anti-TNF antibody), and eculizumab (anti-C5 antibody) can effectively mitigate the CRS, which are nevertheless incapable of reducing mortality in COVID-19 patients (Bian et al. 2020; Mehta et al. 2020).

Among antiviral drugs, chloroquine (CQ) and its derivative hydroxychloroquine (HCQ), are cheap and safe. Their pharmacokinetic properties have also already been approved in the treatment of such viral infections as malaria (Lei et al. 2020). In addition to anti-viral activity, CQ acts as an anti-inflammatory agent that treats autoimmune disorders, including rheumatoid arthritis (Nirk et al. 2020).

Studies have revealed CQ's broad-spectrum antiviral activity through several mechanisms, including prevention of virion assembly and formation of new viral particles through the alkalization of low $\mathrm{pH}$ organelles, especially lysosome. It has also proven to be preventive of the uptake and endocytosis of nanoparticles within the size range of $60-140 \mathrm{~nm}$ via the impairment of glycosylation in the cellular receptors of SARS-CoV (Yan et al. 2013; Wei et al. 2020), a process which weakens affinities between ACE2 and SARS-CoV-2 (Vincent et al. 2005).

$\mathrm{CQ}$ also plays an important role in reducing the transfer of pro-inflammatory agents and receptors into the cell membrane (Ganesan et al. 2018). Such capabilities may account for CQ's potent efficacy in COVID-19 treatment. Since the early In-vitro studies by Wang, chloroquine has been found to be highly effective in the control of SRS-COV-2 infection. The number of studies and clinical trials to test the efficacy and safety of chloroquine in the treatment of COVID19 has increased significantly (Cortegiani et al. 2020; Gao et al. 2016; Gautret et al. 2020).

To date, more than twenty clinical trials, all in China, have examined the effect of CQ in COVID-19 patients. The characteristics of the clinical trials and the primary results have been reported and presented as a table in a study carried out by Cortegiani et al. (2020).

A combination of the two protease inhibitors lupinavir and ritonavir was another option COVID19 treatment (Nutho et al. 2020). The use of these drugs in COVID-19 treatment basically has to do with the earlier confirmed success against SARS-CoV-1 virus and the coronavirus that causes MERS (Yao et al. 2020).

These drugs inhibit a responsible enzyme called 3-chymotrypsin-like protease (3C-like), which acts as a crucial enzyme in the breaking down of polyproteins into two involved enzymes in virus replication, including RNA-dependent RNA polymerase and helicase (Nutho et al. 2020).

The result of studies on the vitro model for SARSCoV-2 infection suggest that the Lopinavir-ritonavir combination form is more effective than when either is applied alone (Choy et al. 2020; Kang et al. 2020).

A systematic review of randomized controlled trials conducted by Tejas in 2021 to evaluate the efficacy and safety of lupinavir-ritonavir in COVID-19 showed no considerably different results when treating the patient with a combination of lupinavir-ritonavir compared to others who had not received this treatment. In addition to the use of lopinavir-ritonavir related with high risk of adverse events than treated patients with the umifenovir as control group (Patel et al. 2021).

Two other drugs, Nafamostat and camostat, which have been approved in Japan to be used as treatment pancreatitis as they subdue serine proteases, including extracellular proteases TMPRSS2 (Hoffmann et al. 2020a, b; Hoffmann et al. 2021).

By blocking virus-membrane fusion, a downregulation of TMPRSS2 significantly reduced cellular infection rate (Hoffmann et al. 2021).

The initial results of cell culture and animal studies determine that this well-known drugs not only maintain an excellent safety profile but also act as a promising drug candidate in fighting COVID-19. However, more experimental data are needed to extensively use it to treat patients suffering from COVID-19 (Breining et al. 2021).

In addition, a plethora of drugs such as Nitazoxanide, Ivermectin, Corticosteroids and Tocilizumab and Sarilumab and still many other unknown or lesserknown drugs have been investigated by scientists and researchers around the world in the hope of unveiling an effective cure against the COVID-19 pandemic.

As the purpose of the present study was to exclusively investigate the treatment efficacy of MSC and MSC-derived exosomes, it found no further 
Table 1 Detailed information of completed clinical studies for MSC or EVs therapy of COVID-19 registered at Clinicaltrials.gov through April 2021

\begin{tabular}{|c|c|c|c|c|c|c|c|c|}
\hline Intervention & $\begin{array}{l}\text { NCT } \\
\text { number }\end{array}$ & $\begin{array}{l}\text { Source of } \\
\text { stem cell }\end{array}$ & Phase & $\begin{array}{l}\text { Dose \& } \\
\text { timing }\end{array}$ & $\begin{array}{l}\text { Rout of } \\
\text { administration }\end{array}$ & $\begin{array}{l}\text { Participants } \\
\text { number }\end{array}$ & $\begin{array}{l}\text { Study } \\
\text { design }\end{array}$ & Location \\
\hline \multirow[t]{7}{*}{$\begin{array}{l}\text { Mesenchymal } \\
\text { stem cells }\end{array}$} & NCT04473170 & $\begin{array}{l}\text { Autologous } \\
\text { NHPBSC }\end{array}$ & $\mathrm{I} / \mathrm{II}$ & N.A & i.n & 146 & $\begin{array}{l}\text { Randomized, } \\
\text { open label }\end{array}$ & $\begin{array}{l}\text { Abu Dhabi Stem Cells } \\
\text { Center, } \\
\text { United Arab } \\
\text { Emirates }\end{array}$ \\
\hline & NCT04522986 & MSC & I & $\begin{array}{l}4 \text { times dose, } \\
1 \times 10^{8} \text { cells }\end{array}$ & i.v & 6 & $\begin{array}{l}\text { N/A, open } \\
\text { label }\end{array}$ & $\begin{array}{l}\text { Osaka University } \\
\text { Hospital, } \\
\text { Japan }\end{array}$ \\
\hline & NCT04713878 & MSC & N.A & $\begin{array}{l}\text { Triple dose, } \\
1 \times 10^{6} \text { cells/ } \\
\mathrm{kg} / \text { dose }\end{array}$ & i.v & 21 & $\begin{array}{l}\text { Randomized, } \\
\text { open label }\end{array}$ & $\begin{array}{l}\text { University of Health } \\
\text { Sciences, Turkey }\end{array}$ \\
\hline & NCT04288102 & UC-MSC & II & $\begin{array}{l}\text { Triple dose, } \\
4 \times 107 \text { cells } \\
/ \text { dose }\end{array}$ & i.v & 100 & $\begin{array}{l}\text { Randomized, } \\
\text { double-blind }\end{array}$ & $\begin{array}{l}\text { 1. General Hospital of } \\
\text { Central Theater } \\
\text { Command } \\
\text { 2. Maternal and Child } \\
\text { Hospital of Hubei, } \\
\text { China } \\
\text { 3. Wuhan } \\
\text { Huoshenshan } \\
\text { Hospital, China }\end{array}$ \\
\hline & NCT04535856 & $\begin{array}{l}\text { Allogenic } \\
\text { MSC }\end{array}$ & I & $\begin{array}{l}\text { Low-dose: } \\
5 \times 10^{7} \text { cells, } \\
\text { High-dose: } \\
5 \times 10^{7} \text { cells }\end{array}$ & N.A & 9 & $\begin{array}{l}\text { Randomized, } \\
\text { double-blind }\end{array}$ & $\begin{array}{l}\text { University of } \\
\text { Hassanudin/ Dr. } \\
\text { Wahidin } \\
\text { Sudirohusodo } \\
\text { Hospital, Indonesia }\end{array}$ \\
\hline & NCT04355728 & UC-MSC & $\mathrm{I} / \mathrm{II}$ & $\begin{array}{l}\text { Double dose, } \\
100 \times 10^{6} \\
\text { cells/infusion }\end{array}$ & i.v & 24 & $\begin{array}{l}\text { Randomized, } \\
\text { double-blind }\end{array}$ & $\begin{array}{l}\text { Diabetes Research } \\
\text { Institute, University } \\
\text { of Miami, Miller } \\
\text { School of Medicine, } \\
\text { United States }\end{array}$ \\
\hline & NCT04492501 & BM-MSC & N.A & $\begin{array}{l}\text { Single dose, } \\
2 \times 10^{6} \text { cells/ } \\
\mathrm{kg}\end{array}$ & N.A & 600 & $\begin{array}{l}\text { Non- } \\
\text { randomized, } \\
\text { open label }\end{array}$ & $\begin{array}{l}\text { Pak Emirates Military } \\
\text { Hospital, Pakistan }\end{array}$ \\
\hline $\begin{array}{l}\text { Extracellular } \\
\text { vesicles }\end{array}$ & NCT04491240 & MSC-EV & I/II & $\begin{array}{l}\text { Twice a day, } \\
10 \text { days, } \\
0.5-2 \times 10^{10} \\
\text { particle }\end{array}$ & i.n & 30 & $\begin{array}{l}\text { Randomized, } \\
\text { double-blind }\end{array}$ & $\begin{array}{l}\text { Medical Centre } \\
\text { Dinasty, Russian } \\
\text { Federation }\end{array}$ \\
\hline
\end{tabular}

NHPBSC non-hematopoietic peripheral blood stem cell, $M S C$ mesenchymal stem cell, $U C$ umbilical cord, $B M$ bone marrow, $N . A$ not applicable, i.n intranasal, i.v intravenous, $E V$ extracellular vesicle

room for a full review of various types of pharmaceutical solutions.

Results from the transfer of the neutralized antibodies from patients, who have recovered during the periods prior to MERS and SARS coronavirus outbreaks, suggest that convalescent plasma (CP) may help with a quick viral clearance, and induce clinical benefits (Xi 2020). Generally, the results obtained from COVID-19 convalescent plasma are highly contradictory and in more cases than not, are rejected as stable epitopes are required, while SARS-
$\mathrm{CoV}-2$ is an RNA virus in which genome is constantly mutating (Xi 2020; Zhang et al. 2020a, b, c).

Another potential treatment can be cell-based therapy It has now been demonstrated that mesenchymal stem cells (MSCs) enjoy significant therapeutic advantages for lung injuries (van Haaften et al. 2009; Han et al. 2019a, b).

Besides MSCs, different immune cells such as natural killer (NK) cells, dendritic cells (DC), T cells, and Cytokine-Induced Killer (CIK) cells as well as secreted exosomes have also been evaluated and are 
found to have beneficial effects in pulmonary pathological conditions mediated by infectious and noninfectious agents (Lee 2017; Jung et al. 2020; Lythgoe and Middleton 2020). Among various cellular sources, the therapeutic function of MSC and its exosomes is consistently reported in different models of acute and chronic pulmonary diseases that can support their use in treating patients with COVID-19 induced pneumonia/ARDS (Fujita et al. 2018; Lythgoe and Middleton 2020).

The present review is set to highlight the therapeutic potentials and challenges facing exosomes derived from MSC in comparison with their cells of origin as a strategy to promote the treatment of patients suffering from COVID-19.

\section{MSC-Based therapy potentials and challenges for COVID-19}

The March 2020 report by Leng and his team confirmed the therapeutic potentials of transplanted MSCs in the amelioration of the pulmonary function of COVID-19 patients for the first time (Leng et al. 2020). Numerous subsequent clinical and pre-clinical studies evaluated such efficacy, safety, and various aspects of MSCs' ability to treat COVD-19. The promising results of phase I/II clinical studies on the application of MSCs in patients with ARDS (Wilson et al. 2015; Laffey and Matthay 2017) encouraged a wide variety of clinical trials in the treatment of COVID-19 with MSCs. Table 1 presents the details of the completed clinical studies.

Given its unique properties, including anti-inflammatory, immune-regulating, and tissue regeneration power, MSC's success in treating COVID-19 infection has come by no surprise. Also, demonstrating the safety of human allogeneic bone marrow in MSCs after intravenous injection into patients with idiopathic pulmonary fibrosis in the first AETHER trial has provided the base for the use of MSCs in the treatment of patients with respiratory disorders (Glassberg et al. 2017). In addition, the safety of MSCs administration in patients with ARDS has been demonstrated across three early-stage completed clinical trials (Han et al. 2019a; Lopes-Pacheco et al. 2020).

The candidacy of MSCs for the treatment of various stages of respiratory disease has led to the revelation of their possible mechanisms, in recent decades (Han et al. 2019a, b; Watanabe et al. 2020). For example, anti-inflammatory and anti-apoptotic effects of MSCs ameliorate lung function through inducing the restoration of epithelial and endothelial cells and also enhancing the clearance of alveolar edema fluid in several models of ARDS. MSCs are able to secrete the anti-inflammatory cytokines (IL-10 and TGF- $\beta$ ) and resulting in a decreased neutrophil recruitment into the injured organs and decrease in the level of pro-inflammatory cytokines (TNF- $\alpha$, IL-8, IL6) (Mohanty et al. 2020). Such function (secreting the anti-inflammatory agent) is part of paracrine activities of MSCs which enables them to manage the function of The cells around them including immune cells (macrophages and $\mathrm{T}$ cells) and non-immune cells (alveolar epithelial cells) (Harrell et al. 2019). Furthermore, MSCs directly interact with various immune cells by averting their proliferation as well as altering their phenotype toward an anti-inflammatory state via the transfer of mitochondria, either directly by tunneling nanotubes (TNT) or indirectly, via secreted extracellular vesicles (Laffey and Matthay 2017; Behnke et al. 2020).

The secretion of various growth factors including fibroblast growth factor-beta (FGFb), vascular endothelial growth factor (VEGF) (Cahill et al. 2016) by MSCs not only significantly inhibit cell apoptosis and decrease oxidative damages, but also induce proliferation and migration of epithelial and endothelial cells to regenerate and replace damaged cells in the pulmonary fibrosis. Such properties are probably useful for the recovery of COVID-19 patients, like results obtained in the study by Harrell's team (Harrell, Sadikot et al. 2019). Distribution alveolar permeability and excessive neutrophil infiltration have repeatedly been reported as hallmark pathophysiology properties of the COVID-19 pandemic (Tomar et al. 2020).

Angiopoietin-1 which is present at secreted soluble factor MSCs through cytoskeletal reorganization and prevention of NF- $\mathrm{KB}$ activity in the alveolar epithelial type II cells, ameliorating alveolar barrier integrity and restoring inflammatory-induced epithelial protein permeability (Anastasiadis 2015).

However, there are several serious challenges of MSC-based therapy that not only reduce their therapeutic efficacy but also limit the accessibility of such 
therapy for millions of infected individuals at this stage in the pandemic.

Despite clinical reports approving the safety in the use of MSCs, some doubts have yet to be completely resolved, including those on the abnormal differentiation, the spontaneous malignant transformation (Drela et al. 2019; Mazini et al. 2019; Saeedi et al. 2019), and the formation of ectopic tissues of transplanted MSCs (Lukomska et al. 2019).

Systemic intravenous (IV) injection is the key route of administration widely used in MSC-based therapy (Kabat et al. 2020). Although the long-term fate of in vitro expanded MSCs after injection remains unclear, the majority of injected cells are, in the short term, entrapped in the capillaries of various organs, especially the lungs (Abreu et al. 2021). However, in the lungs, they experience a fleeting life and disappear $24 \mathrm{~h}$ after injection. Generally, the low efficiency of MSCs engraftment in the lungs is accepted (Behnke et al. 2020). However, the long life term of the grafted MSCs for several weeks (Gu et al. 2015; Harrell et al. 2019) leads to their continued action and increases the likelihood of malignancy due to host immunological tolerance to the MSCs (Behnke et al. 2020; Cruz and Rocco 2020). Finally, very small shares of such cells are relocated to other organs, including liver and spleen (Abreu et al. 2021). Pulmonary embolism due to the obstruction of microcirculation in the periphery and disseminated intravascular coagulation, respiratory and cardiovascular failure, particularly in high doses of MSCs are the serious adverse effects of MSCs therapy (Liao et al. 2017).

In addition, inflammation-induced embolization considerably increases the risk of instant bloodmediated inflammatory reaction (IBMIR) and causes a rapid loss of the majority of infused cells due to activation of innate immune responses, including complement/coagulation cascades (Qu et al. 2021). Such a result may limit the use of MSCs for COVID19 patients with hypercoagulopathy. The use of earlypassage MSCs in lower doses is recommended to reduce the side effects associated with the MSCs prothrombotic profile (Galleu et al. 2017). Changing the immunomodulatory properties of MSCs by lung microenvironment is another challenge that should be taken into consideration. Although MSCs mostly possess anti-inflammatory activity, their immunomodulatory property is completely related to the immune status of the microenvironment (Le Blanc and Mougiakakos 2012; Islam et al. 2019).

In fact, it is suggested that the anti-inflammatory effect of MSCs is heterogeneous (Behnke et al. 2020). Under undesirable environments, MSCs can increase damage through secretion factors in response to the lung microenvironment (Antebi et al. 2018). Islam et al. reported different results of protective activity of MSCs in three different models of lung injury (Islam et al. 2019). Contrary to the protective effect of native MSCs on ventilator-induced lung injury, lung injury with primary acid worsened after exposure to native MSCs due to the development of fibrosis. In order to overcome the lung microenvironment, Islam and his colleagues treated mice with MSCs carrying human gene of IL-10 (MSC ${ }^{\mathrm{IL}-10)}$ or hepatocyte growth factor $\left(\mathrm{MSC}^{\mathrm{HGF}}\right)$. The result indicated the level of proinflammatory cytokines, while TGF- $\beta 1$ and fibrinogen were decreased after $24 \mathrm{~h}$. They also demonstrated that lentivirus [LV] carrying human genes of glutathione peroxidase-1 $\left(\mathrm{LV}^{\mathrm{GPx}-1}\right)$ and for a proper oxidative microenvironment of lungs before MSC administration led to an increase in the antioxidant capacity but reduced the level of $\mathrm{H}_{2} \mathrm{O}_{2}$, cytokines IL-6 and fibronectin. In fact, they indicated that microenvironment at the time of administration is an important factor that determines the MSCs function (Islam et al. 2019).

To reduce the heterogeneous anti-inflammatory effect and improve the appropriate anti-inflammatory phenotype of MSCs, Bustos et al., treated the injured mice with human MSCs preconditioned with serum obtained from ARDS patients. The results showed that preconditioned MSCs exhibited a higher level of cytokines, such as IL-10 and IL-1RN, which lead to an increase in their protective capacity (Bustos et al. 2013).

Meanwhile, changing such properties of MSCs that are related to lung microenvironment may induce drug resistance in a way similar to what has repeatedly been reported in MSC-based anti-cancer therapy (Birru et al. 2020).

The migration and homing capability of MSCs is another critical factor for the efficacy of the MSCbased therapy. In vitro culture conditions such as (hypoxic culture condition, culture confluence), the passage number and the donor's age can alter the homing related physical properties of MSCs (Ullah et al. 2019). For example, the level of chemokine 
receptors such as CXCR4 on the surface of MSCs drop during in vitro serial expansion MSCs and affect their homing ability (Jin et al. 2018). In addition to such inherent limitations, providing and maintaining a large amount of clinical-grade MSCs, required for a large number of patients, is not only very expensive but also difficult and cumbersome.

The mechanism of action of MSCs has yet to be entirely understood, and possibly entails the collection of various signaling pathways. It is generally accepted that a big part of these postulated mechanisms are mediated by the secretion of paracrine factors (Zhou et al. 2019; Batsali et al. 2020). The working role of paracrine mechanisms of MSCs has been observed in order to help improve the airway inflammation of animal models (Fujita et al. 2018). Soluble mediators, which are secreted by MSCs include cytokines, growth factors, miRNA, as well as exosomes, sharing similar functions like parent cells, are responsible for their properties (Jafarinia et al. 2020). Interestingly, follow-up MSCs transplantation in a patient with acute graft-versus-host disease, while emphasizing the relatively short-lived transplanted MSCs, reported no relationship between MSCs transplantation and therapeutic responses. They concluded that the anti-inflammatory effects of MSCs depend on the production and secretion of reparative factors (Von Bahr et al. 2012).

\section{Therapeutic potential of MSC-derived exosomes for COVID-19}

Exosomes are nano-size membranous vesicles with a size range within $30-150 \mathrm{~nm}$. They are secreted by many cell types into various body fluids (Modani et al. 2021). In physiological and pathological conditions, exosomes have a critical role in cell-to-cell communications through the transport of various biological molecules like miRNA and proteins into target cells (Modani et al. 2021). Unlike apoptotic bodies and micro-vesicles, which are derived from the cell surface, exosomes are generated by endosomal pathways and load the cytoplasmic content of the origin cell. Therefore, they are a mini version of their origin cell and mimic all of their properties (Pegtel and Gould 2019). Exosomes are among key paracrine effectors secreted by MSCs and due to their biological cargo, which is similar to parental cell, and their ability to preserve healing properties, they are considered as an attractive candidate to replace MSCs in treating various diseases (Joo et al. 2020).

Nontoxicity, low-immunogenicity, high stability, easy storage, and the potential to be produced as an off-the-shelf product are several benefits of exosomes compared to their cellular counterparts that led to their expanding clinical application as new therapeutic surrogates (Jafari et al. 2019).

In addition, the natural functioning of exosomes enables them to deliver their membrane and cytoplasm bio-active components from origin cell to target cells through the fusion of plasma membranes. There are also other unique properties, including a natural ability to freely cross the biological barriers such as Blood Brain Barrier (BBB). Furthermore, biocompatibility is another feature. Due to their root in biological sources and an intrinsic targeting ability, exosomes have been utilized as delivery vehicles for pharmaceutical components in preclinical studies (Guo et al. 2017). These unique properties of exosomes add to immune-modulatory and anti-inflammatory associated with MSCs introduce exosomes derived from MSCs as an interesting tool for therapeutic intervention to deal with the current COVID-19 pandemic situation. Probably, MSC- exosome, in a mechanism difference or similar to parental cells, can prevent the cytokines storm induced by over-reactive immune responses and as well as promote endogenous repair of injured lungs.

\section{Effect of MSC-derived exosomes on lung inflammation}

MSC-derived exosomes inherit immunosuppressive properties from their parental cells. Various mechanisms were probably used by MSC-exosomes to equilibrate the function of the immune system (Chen et al. 2016). One of the key mechanisms is reprogramming and altering the phenotype of various immune cells. For instance, the ability of MSCderived exosomes to promote the survival of alveolar macrophages and change their phenotype from proinflammatory (M1) into the anti-inflammatory (M2) polarization has been confirmed by at least two studies (Rodriguez et al. 2018; Park et al. 2019). The implication of these findings is that exosomes can be a viable alternative to their parental cells. 
Such ability has also been reported for MSCs, which can alter the Treg/Teff ratio toward increased Treg, and boost the secretion of anti-inflammatory cytokine (Del Fattore et al. 2015).

Different studies have found that MSC-exosomes in the inflammatory environment of ARDS, were responsible for reprogramming of macrophages toward reducing the production of TNF- $\alpha$ and IL- 8 as the major pro-inflammatory cytokines, M1-M2 polarization of macrophages and also improving their phagocytosis effects and oxidative phosphorylation (Vats et al. 2006; Phinney et al. 2015; Morrison et al. 2017).

Another mechanism through which MSCs would cause regulation of target cells function is dependent on gene expression regulation via exosome-mediated microRNAs transfer (Gong et al. 2017). As already mentioned, exosomes can change the function of the target cell based on its specific bioactive molecules. MicroRNAs exist within MSC- exosomes such as miR-34a, miR-122, miR-124, miR-127, miR-146a, and miR-195 that have a significant role in inducing the immune-modulatory properties associated with MSCs (Aliotta et al. 2016, 2017). For example, overexpressed miR-122 in MSC-exosomes increase the chemo-sensitivity of hematoma cells through knockdown of its target gene, including cyclin G1 and insulin-like growth factor receptor 1 and trigger apoptosis and cell cycle arrest (Lou et al. 2015).

Also, miR-34a is a master tumor suppressor miRNA which is able to regulate critical genes in tumor evolution and progression of cancer such as BCL2, MYC, CDK4/6, NOTCH1, MET, and CD44 (Slabáková et al. 2017). Song et al. showed that MiR146, a well-known anti-inflammatory miRNA, selectively packaged into exosomes derived from MSCs and could induce macrophages towards M2 phenotypes (Song et al. 2017).

In addition, MSC- exosomes carried a high-level mRNA of cyclooxygenase (COX)-2 enzymes inducing the production of prostaglandin E2 (PGE2). PGE2 is considered as a critical key to switch the M1 phenotype to the M2 phenotype of macrophages (Németh et al. 2009).

Systemic administration of MSCs and MSC-exosomes in aspergillus hyphal extract induced allergic airway inflammation in immunocompetent mice, while emphasizing the better impact of MSC-exosomes than MSCs, and thus reported the mitigation of allergic airway inflammation induced by Th2/Th17 through switching the Th2/Th17 inflammatory response toward the Th1 response, and decreased eosinophilic and neutrophilic-mediated allergic inflammation in the lung tissue (Cruz et al. 2015). Phinney et al. in 2015 reported that exosomes secreted by MSCs in the environmental oxidative stress in animal models of chronic obstructive pulmonary disease (COPD) modulated the function of macrophages through a mitochondrial transfer and blocked the central inflammatory pathway, including TLRs and NF- $\mathrm{KB}$ by transferring regulatory microRNAs such as miR-451 which is known as the TNF suppressor (Phinney et al. 2015).

Overall, it can be concluded that MSC-exosomes could possibly accelerate the recovery process in COVID-19 patients via re-equilibrating the dysregulated function of immune systems.

\section{Tissue regenerative potential of MSC-based exosomes and its implications in treating COVID- 19}

Disruption of lung epithelial-endothelial barrier integrity, fibrosis, and thickening in alveolar walls through the infiltration of monocytes and alveolar macrophages that lead to dysfunctional alveolar-capillary gas exchange and hypoxia happen in the late stages of SARS-CoV-2 infection (Leeming et al. 2021). Several studies have well demonstrated the suppressive properties of the immune system and the regeneration of tissues damaged by MSC-exosomes in various lung diseases in vitro and in animal models (Willis et al. 2017; Braun et al. 2018; Khatri et al. 2018). Additionally, MSC- exosomes in a dose-dependent manner are effective in restoring and repairing of lung injury arising from ARDS (Monsel et al. 2015; Shah et al. 2019).

High levels of angiopoietin-1 mRNA which is a known as an anti-inflammatory and anti-permeability agent, in MSC- exosomes, reduce permeability pulmonary edema and decrease the infiltration of neutrophils (Mei et al. 2007; Gennai et al. 2015; Park et al. 2019). Furthermore, animal models of various lung disorders (asthma and COPD) in recent studies showed that exosomes secreted by MSCs through PI3K/Akt pathway were able to restore the expression of extracellular matrix (ECM) proteins, and reduced 
the parenchymal collagen content (Belik et al. 2016; de Castro et al. 2017).

Also, Park and colleagues reported a jump in alveolar fluid clearance (AFC) after MSC-exosomes administration through upregulation of the sodium channel and keratinocyte growth factor (KGF) in alveolar epithelial cells (Park et al. 2019).

Preclinical animal models studies revealed that MSC-exosomes could also reduce pulmonary hypoxic hypertension (Lee et al. 2012; Chen et al. 2014; Hogan et al. 2019). For example, Lee et al. in 2012 evaluated the cytoprotective action of MSC-exosomes in hypoxia pulmonary arterial hypertension (PAH) mice models. They reported reverse hypoxic pulmonary hypertension via preventing the hypoxic activation by suppressing the STAT3 signaling pathway, and overexpressed the miR-17 superfamily and miR-204 in the lungs (Lee et al. 2012). In general, upregulating the expression of tricarboxylic acid (TCA) cycle enzymes, including pyruvate dehydrogenase (PDH) and glutamate dehydrogenase 1 (GLUD1) as well as improving the mitochondrial function of pulmonary cells are MSC-EXO mechanisms in reducing PAH complications (Hogan et al. 2019). Such results indicate the high potential of MSC-exosomes in repairing COVID-19-associated lung damage. However, obtaining better results require an in-depth study of the mechanism and vascular effects of SARS-CoV2 infection.

\section{Antiviral activity of MSC-derived exosomes}

The three mentioned functions of MSC-exosomes include anti-inflammatory properties, immune modulation, and tissue protection properties performed through the alteration of host cell function. MSCexosomes also have natural antiviral activity resulting from endogenous cargoes, including mRNA and miRNA (Popowski et al. 2021).

Immune-modulatory properties of $\mathrm{T}$ regulatory cells induced by MSC-exosomes might increase virus clearance by TCD8 cells in neonatal mice infected with influenza A virus (IAV) (Oliphant et al. 2015).

For example, Khatri et al. reported the antiviral activity of MSC-exosomes in a pig model of influenza virus. They showed that such activity is dependent upon the presence of mRNA and miRNAs in exosomes derived from MSCs and their transport to lung epithelial cells. They also demonstrated the reduction in the inflammatory condition by averting the expression of proinflammatory cytokine and chemokine after MSC-exosomes administration in pig models (Khatri et al. 2018).

Also inducing the expression of $\mathrm{T}$ regulatory cells by MSC-exosomes might increase virus clearance by TCD8 cells in an unknown mechanism (Oliphant et al. 2015).

Antiviral abilities of MSC-exosomes can be promoted in engineered types, such as the use for delivery of loaded antiviral drugs and the production of engineered exosomes by the expression of antibodies and receptors on their surface as nano-decoys. In the nano-decoys complex, exosomes act as a cell-mimic. Through binding with the viruses, they do block the initialization of the virus into the host cell, which is done via tagging the virus, thanks to the physical link, thus increasing the pre-infection chances of elimination by immune cells (Rao et al. 2020). For example, the presence of ACE2 on the surfaces of lung-derived exosomes effectively trapped viral particles before infection (Rao et al. 2020; Zhang et al. 2020a, b, c).

The engineering of MSC-derived exosomes to express ACE2 on their surface, along with their other known properties, is likely to have stronger potential in the fight against SARS-CoV-2, confirming results obtained by Shennawy et al. that revealed the ability of plasma isolated ACE2-expressing (ACE2+) exosomes from COVID-19 patient in neutralization of SARS-CoV-2 infection (El-Shennawy 2020; Hoffmann et al. 2020a, b). Table 2 summarizes the therapeutic benefits of MSCs and their exosomes in lung injuries.

\section{MSCs and MSC-derived exosomes: a comparison of efficiency in COVID-19 treatment}

The debate over whether exosomes or cell therapy work better remains open-ended. Despite having almost the same therapeutic effects, either of the two strategies has its own advantages and disadvantages that can affect the choice of a workable strategy for the treatment of COVID-19 patients. Here we review some advantages of exosomes over MSCs in treating COVID-19 as we also discuss the present challenge faced by exosome-based therapy. 
Table 2 The comparison of therapeutic benefits of MSC and their exosomes in lung injuries

\begin{tabular}{|c|c|c|c|}
\hline Therapeutic roles & MSC therapy & MSC-exosome therapy & References \\
\hline \multicolumn{4}{|l|}{ Immunomodulatory activity } \\
\hline$\downarrow$ Pro-inflammatory cytokine & $\checkmark$ & $\boldsymbol{v}$ & Phinney et al. (2015) \\
\hline$\uparrow$ Anti-inflammatory cytokine & $\checkmark$ & $\checkmark$ & Del Fattore et al. (2015) \\
\hline$\rightarrow$ M1-M2 phenotype polarization & $\checkmark$ & $\checkmark$ & Park et al. (2019) \\
\hline $\begin{array}{c}\bar{T} \text { Immune cells proliferation } \& \text { activation } \\
\text { directly }\end{array}$ & $\checkmark$ & $\checkmark$ & Harrell et al. (2019) \\
\hline$\uparrow \mathrm{T}_{\text {reg }} / \mathrm{T}_{\text {eff }}$ ratio & $\checkmark$ & $\checkmark$ & Del Fattore et al. (2015) \\
\hline$\uparrow$ Oxidative phosphorylation in MQ & $\checkmark$ & $\checkmark$ & Morrison et al. (2017) \\
\hline$\uparrow$ Alveolar MQ survival & $\checkmark$ & $\checkmark$ & Hogan et al. (2019) \\
\hline \multicolumn{4}{|l|}{ Tissue regeneration activity } \\
\hline Trans differentiation function & $\checkmark$ & - & Behnke et al. (2020) \\
\hline Cytoprotective function & $\checkmark$ & $\checkmark$ & Lee et al. (2012) \\
\hline Improvement of Mitochondrial function & $\checkmark$ & $\boldsymbol{v}$ & Hogan et al. (2019) \\
\hline$\overline{\boldsymbol{T}}$ Cell apoptosis & $\checkmark$ & $\checkmark$ & Lou et al. (2015) \\
\hline$\rightarrow$ Epithelial \& endothelial cell proliferation & $\checkmark$ & $\checkmark$ & Al-Khawaga and Abdelalim (2020) \\
\hline$\uparrow$ Anti-fibrosis function & $\checkmark$ & $\checkmark$ & Islam et al. (2019) \\
\hline$\uparrow$ Alveolar epithelium function & $\checkmark$ & $\boldsymbol{v}$ & Park et al. (2019) \\
\hline$\downarrow$ Permeability pulmonary edema & $\checkmark$ & $\checkmark$ & Park et al. (2019) \\
\hline$\downarrow$ Pulmonary hypoxic hypertension & $\checkmark$ & $\checkmark$ & Hogan et al. (2019) \\
\hline \multicolumn{4}{|l|}{ Antiviral activity } \\
\hline Carry antiviral cargo & $\checkmark$ & $\boldsymbol{v}$ & Khatri et al. (2018) \\
\hline$\uparrow$ Neutralization viral infection & - & $\boldsymbol{v}$ & El-Shennawy et al. (2020) \\
\hline$\overline{\mathrm{T}}$ Viral entrance into cells & - & $\checkmark$ & Rao et al. (2020) \\
\hline$\uparrow$ Virus clearance through $\mathrm{T}$ cell activation & $\checkmark$ & $\checkmark$ & Oliphant et al. (2015) \\
\hline
\end{tabular}

MSC mesenchymal stem cells, EV extracellular vesicle, $M Q$ macrophages, Treg T regulatory cell, Teff T effector cell, AFC alveolar fluid clearance. The arrows represent: increase, $\uparrow$; decrease $\downarrow$; induction, $\rightarrow$; inhibition, $\overline{\mathbf{T}}$

1. The comparison of exosomes function and their source cell shows that exosomes are able to exert the same impact through a different or similar mechanism, and in many cases are even more effective (Phinney and Pittenger 2017). For instance, Del Fattore et al. verified the better immunomodulatory function of MSC-derived exosomes than the origin cells. They realized that in a mechanism, which probably differs from parent cells, MSC-derived exosomes alter the PMSC Treg/Teff ratio toward increased CD4 ${ }^{+-}$ $\mathrm{CD} 25^{+} \mathrm{CD} 127$ low Tregs and also, change the amount of anti-inflammatory cytokine, including IL-10 increased (Del Fattore et al. 2015).

2. Due to their small size, exosomes are able to cross thin veins and even the blood-brain barrier, while
MSCs can immediately get trapped in the lungs and create the pulmonary embolism and infarct, especially after intravenous injection (Aryani and Denecke 2016). For example, intravenous injection of inoxine-labeled MSCs demonstrated high initial uptake and trapped a large number of MSCs in the lungs due to their relatively large size $(\approx$ $25 \mu \mathrm{m}$ in suspension) (Ye et al. 2020).

3. Due to the absence of MHC class I-II on their surface, both allogeneic and autologous MSCderived exosomes are safe. In a prospective nonrandomized cohort study in April 2020, Sengupta evaluated the safety and therapeutic efficacy of exosomes derived from allogeneic BMSCs in COVID-19 patients (Sengupta et al. 2020). After $72 \mathrm{~h}$ of a single intravenous administration of 
exosomes, adverse effects were not observed and all safety endpoints of the study were met. 17 patients $(71 \%)$ out of the 24 under observation recovered. Clinically, the capacity to restore oxygenation of patients ameliorated. The result of the laboratory test also demonstrated the reconstitution of immunity through growth in the neutrophil and lymphocyte count, suppression of cytokine storm via declining the acute phase reactants, C-reactive protein, and ferritin. In addition to that finding, they reported that MSCderived exosomes are an ideal and novel therapeutic option for severe COVID-19 (Sengupta et al. 2020). While as previously stated, abnormal differentiation and spontaneous transformation about MSCs is still a concern.

4. Removing such restrictions as the lineage of exosomes reference [Embryonic stem cells (ESC) and induced pluripotent stem cells (iPS)] combined with developed technology for producing and cryopreserving grade-clinical exosomes under GMP guidelines makes their production much easier and consequently less expensive (Whitford and Guterstam 2019). For example, the exosomes production quality control could start from the first step, which is the donor competency analysis and is subsequently implemented in all stages. Also, some production processes such as final concentration and vial filling could be performed in a fully automatic manner, representing an example of a closed-loop system. And the final product of each exosomes batch is analyzed for size, homogeneity, quantity as well as positive and negative markers (Muraca et al. 2017)

5. Easy manipulation of exosomes and engineering exosomes allows the production of a wide range of products tailored to the intended purpose through various direct and indirect techniques. It is also possible to improve the therapeutic effect of the exosomes by loading therapeutic drugs (Wang et al. 2016; Armstrong et al. 2017).

6. Another advantage of MSC-exosomes is that parent cells in the treatment of COVID-19 allow for a nasal administration of antiviral-loaded exosomes and a direct transfer of them into the nasal mucosa and the lungs that are most frequently exposed to the coronavirus and thus serve as the destination where the proposed drugs are expected to effectively work (Ziegler et al. 2020; Popowski et al. 2021)

However, there are still significant roadblocks on the development of exosomes-based therapies.

The first challenge is to find the appropriate cell source that meets the therapeutic goal. Various factors such as tissues of origin, the donor age, and culture conditions might also alter the therapeutic properties, including immunomodulatory and differentiation capacity of MSCs (Gao et al. 2016).

The second issue is the integral dependence of exosomes production on cell culture. exosomes are secreted by cells. Thus, producing them in large amounts requires the production of large amounts of cells without compromising the genotypic and phenotypic properties of their producing cells (Whitford and Guterstam 2019).

Obtaining a huge number of cells in a process which is less time-consuming and more cost-effective is yet another step toward limiting stable products. It definitely restricts the production of large quantities of stem cell-conditioned medium which carry cellderived exosomes (Colao et al. 2018).

However, the success of cell culture development based on technologies to increase surface area has largely overcome such a limitation. Yet the complexity of controlling the environmental parameters including the risk of phenotypic alteration and the formation of apoptotic bodies can decrease the quality and quantity of the final product (Agrahari et al. 2019).

As exosomes are the secreted products of cells, perfusion bioreactors culture cells such as hollow-fiber perfusion bioreactors provide sufficient mass transfer in the culture and also continuous high cell density culture and effectively reduce the cellular requirement for serum factors (Whitford and Guterstam 2019). Integra CELLine systems are new flask 'bioreactors' that are able to concentrate exosomes within a membrane compartment and allow transfer of culture medium for a long period of time (Whitford et al. 2015). Increasing the concentration of exosomes effectively reduces the downstream processing steps, and thus the resulting costs (Whitford et al. 2015).

Another limiting issue associated with the production of exosomes in a large-scale cell cultivation system is the dependence of optimal cell growth on animal serum (Whitford and Guterstam 2019). This is problematic in two ways. The first issue has to do with 
Table 3 A summary of the comparison of MSC-therapy and MSC-exosome therapy for the treatment of COVID-1

\begin{tabular}{|c|c|c|c|}
\hline Is preferred exosome than MSC for COVID- 19 Treatment? & $\begin{array}{l}\text { MSC } \\
\text { therapy }\end{array}$ & $\begin{array}{l}\text { MSC-Exosome } \\
\text { therapy }\end{array}$ & References \\
\hline $\begin{array}{l}\text { Cross thin veins and even the } \\
\text { blood brain barrier(BBB) }\end{array}$ & - & $\boldsymbol{\sim}$ & Guo et al. (2017) \\
\hline Entrapped in the capillaries of non-target orga & $\boldsymbol{\sim}$ & - & Abreu et al. (2021) \\
\hline Pulmonary embolism & $\boldsymbol{V}$ & - & Liao et al. (2017) \\
\hline $\begin{array}{l}\text { Risk of instant blood-mediated } \\
\text { inflammatory reaction (IBMIR) }\end{array}$ & $\boldsymbol{\sim}$ & - & Qu et al. (2021) \\
\hline Induce drug resistance & $\boldsymbol{V}$ & - & Birru et al. (2020) \\
\hline Intrinsic targeting ability & $\boldsymbol{\sim}$ & $\boldsymbol{\sim}$ & Jin et al. (2018) \\
\hline Safety & - & $\boldsymbol{\sim}$ & Jafari et al. (2019) \\
\hline Abnormal differentiation & & - & Drela et al. (2019) \\
\hline Formation of ectopic tissue & $\boldsymbol{\sim}$ & - & Drela et al. (2019) \\
\hline Prolong circulation time & - & $\checkmark$ & Sengupta et al. (2020) \\
\hline Change their properties under lung microenvironment & $\boldsymbol{\sim}$ & - & Behnke et al. (2020) \\
\hline $\begin{array}{l}\text { Easy manipulation to improve stability and therapeutic } \\
\text { properties }\end{array}$ & - & $\boldsymbol{\sim}$ & Armstrong et al. (2017) \\
\hline Procoagulant activity & $\boldsymbol{\sim}$ & $\checkmark$ & Tripisciano et al. (2017) \\
\hline High stability & - & $\boldsymbol{\sim}$ & $\begin{array}{l}\text { Whitford and Guterstam } \\
\text { (2019) }\end{array}$ \\
\hline Direct transfer (nasal administration) & - & $\boldsymbol{\sim}$ & Ziegler et al. 2020) \\
\hline Cost & High & Low & Colao et al. (2018) \\
\hline
\end{tabular}

the increased risk of viral contamination while the second deals with the high presence of large numbers of exosomes in animal serums that if not removed before cell culture may enter the final product and render it unacceptable before being injected. An alternative suggestion is serum-free and xeno-free culture media components but provided that it maintains comparable therapeutics properties of the exosomes product (Phelps et al. 2018).

A significant advantage of exosomes compared to adherent producer cells such as stem cells is their simple isolation from the conditioned medium (Colao et al. 2018). However, adherent cell products are enzymatically detached, which increases downstream processing operations costs and purification times while reducing efficiency that results in loss of product (Whitford et al. 2015).

In downstream processing, four separation methods are generally used to purify exosomes, including sedimentation force, affinity isolation, filtration, and polymeric precipitation (Gardiner et al. 2016). Each of these methods for different reasons may not be appropriate for larger-scale production of exosomes.

For example, the limitations of ultracentrifugation such as the lengthy process, repeated steps, and disruption of exosomes during separation are inconsiderable. However, as for nanospecific precipitation, it not only requires downstream processing to remove PEG from the final product, but also reduces the purity of the final product due to the co-isolation of various types of EVs and proteins (Chen et al. 2020).

Affinity purification through antibodies against exosomes surface markers could be the best method for exosomes purification that leads to a purer and more homogeneous product compared with other methods (Willis et al. 2017).

The proposed ideal processes for exosomes purification are sequence-based processes designed from a combination of filtration and chromatographic-based methods. A fine example of this strategy is tangential flow filtration, which is capable of purifying MSCexosomes with a 125-fold concentration (Kim et al. 2018). 
Another challenge is the heterogeneity of the exosomes subpopulations. Exosomes have been used in almost all studies to refer to isolated extracellular vesicles (Tkach et al. 2018; Willms et al. 2018). Part of such ambiguity is due to the inability of extraction methods to separate exosomes subtypes, as well as the lack of accurate descriptions for each type of exosomes, as many of their properties overlap between exosomes subtypes, such as size and markers (Willms et al. 2018). The importance of such an issue was recognized when it was observed that exosomes isolated with different sizes of dendritic cells could induce different classes of $\mathrm{T}$ cells such as cytotoxic $\mathrm{T}$ cells, helper $\mathrm{T}$ cells, and regulatory $\mathrm{T}$ cells (Kowal et al. 2016). In addition, quantitative determination of the bioactive substance of the exosomes product remains a major challenge in the development of its therapeutic scales (Willis et al. 2018). According to the FDA standards, potency is defined as the specific ability or capacity of a product to elicit the desired result (Pachler et al. 2017). It is necessary that a unique potency unit for the assessment of exosomes potency be applied to standardize practices and overcome the inconsistencies and variations between batch-to-batch products. Of note is the point that in vitro potency, assays must be able to accurately predict outcomes in vivo so that it is be specific for each disease, fit-fordesignated purpose, and relevant to the final functional (Colao et al. 2018). For example, to define the potency of MSC-exosomes, their immune-regulating properties have been used to induce IL-10 from mononuclear cells after the incubation process with them (Kim et al. 2020).

Another hurdle of exosome-based clinical trials is the pro-coagulation activity assigned to them (Tripisciano et al. 2017). This is a biological property of exosomes and their origin cell as they carry the same receptors and proteins on their surface, including phosphatidylserine, which is well-known as a critical component in promoting coagulation activity and tissue factor as the main initiator of coagulation (Bernimoulin et al. 2009; Tripisciano et al. 2017). Cellular origin, passage number, and viability are other important factors that are able to strengthen the coagulation cascade in blood after exosomes administration (Tripisciano et al. 2017; Nielsen et al. 2018; Silachev et al. 2019).

A proposed solution to prevent the procoagulant activity of exosomes is treatment with a combination of anticoagulants agents (heparin and bivalirudin). While Silachev et al. demonstrated that monotherapy is done only by heparin due to the fact that using different proteins in the procoagulant activity of exosomes is not effective (Silachev et al. 2019). Also, the quality of the final product resulting from the isolation of exosomes is another effective factor in minimizing exosomes coagulation activity. Nielsen et al. showed that adding to the purity of isolated exosomes and removing more contaminants, including plasma proteins and lipoproteins, reduced the risk of thrombosis in cancer patients (Nielsen et al. 2018). Many hospitalized patients who suffered from COVID-19 are dealt with increased risk of coagulopathy and venous thromboembolism, and currently dispense anticoagulation and fibrinolytic drugs (Barnes et al. 2020; Mancia et al. 2020; Smith et al. 2020). Therefore, it is proposed that further analysis be undertaken with utmost caution to prevent or reduce the plausible complication of exosomes in COVID-19 patients, who are facing a high risk of thrombosis.

Contrastingly, a recent study by Jamshidi et al. demonstrated that MSCs can decrease the risk of thrombosis and coagulation in COVID-19 through the equalization of hemostasis factors (Jamshidi et al. 2021). Several mechanisms are involved in this function, (1) MSCs reduce apoptosis of vascular endothelial cells and subsequently the vessel injury and disseminated intravascular coagulation (DIC) through decreasing the expression of pro-inflammatory cytokines such as TNF- $\alpha$, IFN- $\gamma$, IL-6. (2) Suppression of immune cells, including T-cytotoxic lymphocytes, NK cells, and B cells by MSCs prevent the formation of microthrombi fibrin and also, (3) MSCs alter the differentiation of macrophages polarization toward M2 phenotype, which promotes neovascularization and tissue repair (Zhang et al. 2019; Jamshidi et al. 2021).

Table 3 is a summary of the comparison of MSCtherapy and MSC-exosomes therapy for the treatment of COVID-19.

Such abilities are likely to be present in the exosomes secreted from them, which adds another benefit to MSC-exosomes for the treatment of patients suffering from COVID-19. 


\section{Conclusion}

Creating a new clinical treatment strategy requires not only years of pre-clinical studies but also a successful completion of three different clinical phases. In the last decade, the therapeutic potential of MSC-exosomes and their abilities in both preclinical and animal models have been evaluated on the hopes for a new cure toward incurable diseases. The COVID-19 crisis is an opportunity to assess the knowledge gained out of MSC-exosomes therapeutic potentials. The result of the first clinical study conducted in China shows that MSC-exosomes can be effective in averting the progression of COVID-19 and healing damaged lungs. In addition, the intrinsic features such as safety, stability, and scalability make exosomes an ideal and practical treatment option for COVID-19. Despite such significant achievements, there is still a long way ahead toward accessing exosome-based ready-to-use products on the shelf, before which a great deal of effort is required to solve technical problems surrounding such a gain. Some of those issues have to do with the biological nature of MSC-exosomes, such as heterogeneity, others are rooted in the in vitro production process, including variability associated with culture conditions. Therefore, the production of large, purified and uncontaminated amounts, with clinicalgrade of exosomes is the main challenge complicating the process of exosome-based treatment.

\section{Acknowledgements Not applicable.}

Authors' contributions All authors contributed to the study conception and design. All authors reviewed this draft, contributed and approved the final manuscript.

Funding Not applicable.

Data Availability Not applicable.

\section{Declarations}

Conflict of interest The authors declare that they have no competing interests.

\section{Ethical approval and consent to participate Not applicable.}

Consent for publication All the authors approved the present version for publication purposes and agreed to hold accountability for all aspects of the work.

Research involving human participants and/or animals Not applicable.
Informed consent Not applicable.

\section{References}

Abreu SC, Lopes-Pacheco M, Weiss DJ, Rocco PR (2021) Mesenchymal stromal cell-derived extracellular vesicles in lung diseases: current status and perspectives. Front Cell Dev Biol. https://doi.org/10.3389/fcell.2021.600711

Aggarwal G, Cheruiyot I, Aggarwal S, Wong J, Lippi G, Lavie CJ, Henry BM, Sanchis-Gomar F (2020) Association of cardiovascular disease with coronavirus disease 2019 (COVID-19) severity: a meta-analysis. Curr Probl Cardiol 45:100617

Agrahari V, Agrahari V, Burnouf P-A, Chew CH, Burnouf T (2019) Extracellular microvesicles as new industrial therapeutic frontiers. Trends Biotechnol 37(7):707-729

Aliotta JM, Pereira M, Wen S, Dooner MS, Del Tatto M, Papa E, Goldberg LR, Baird GL, Ventetuolo CE, Quesenberry PJ (2016) Exosomes induce and reverse monocrotaline-induced pulmonary hypertension in mice. Cardiovasc Res 110(3):319-330

Aliotta JM, Pereira M, Wen S, Dooner MS, Del Tatto M, Papa E, Cheng Y, Goldberg L, Ventetuolo CE, Liang O (2017) Bone marrow endothelial progenitor cells are the cellular mediators of pulmonary hypertension in the murine monocrotaline injury model. Stem Cells Transl Med 6(7):1595-1606

Anastasiadis P (2015) Regulation of cytokine-mediated vascular permeability under flow-induced shear stress. University of Hawai at Manoa, Manoa.

Antebi B, Walker KP, Mohammadipoor A, Rodriguez LA, Montgomery RK, Batchinsky AI, Cancio LC (2018) The effect of acute respiratory distress syndrome on bone marrow-derived mesenchymal stem cells. Stem Cell Res Ther 9(1):1-13

Armstrong JP, Holme MN, Stevens MM (2017) Re-engineering extracellular vesicles as smart nanoscale therapeutics. ACS Nano 11(1):69-83

Aryani A, Denecke B (2016) Exosomes as a nanodelivery system: a key to the future of neuromedicine? Mol Neurobiol 53(2):818-834

Barnes GD, Burnett A, Allen A, Blumenstein M, Clark NP, Cuker A, Dager WE, Deitelzweig SB, Ellsworth S, Garcia D (2020) Thromboembolism and anticoagulant therapy during the COVID-19 pandemic: interim clinical guidance from the anticoagulation forum. J Thromb Thrombol 50:72-81

Batsali AK, Georgopoulou A, Mavroudi I, Matheakakis A, Pontikoglou CG, Papadaki HA (2020) The role of bone marrow mesenchymal stem cell derived extracellular vesicles (MSC-EVs) in normal and abnormal hematopoiesis and their therapeutic potential. J Clin Med 9(3):856

Behnke J, Kremer S, Shahzad T, Chao C-M, Böttcher-Friebertshäuser E, Morty RE, Bellusci S, Ehrhardt H (2020) MSC based therapies-new perspectives for the injured lung. J Clin Med 9(3):682

Belik D, Tsang H, Wharton J, Howard L, Bernabeu C, WojciakStothard B (2016) Endothelium-derived microparticles from chronically thromboembolic pulmonary hypertensive 
patients facilitate endothelial angiogenesis. J Biomed Sci 23(1):1-11

Bernimoulin M, Waters E, Foy M, Steele B, Sullivan M, Falet H, Walsh M, Barteneva N (2009) Differential stimulation of monocytic cells results in distinct populations of microparticles. J Thromb Haemost 7(6):1019-1028

Birru B, Durthi CP, Kacham S, Pola M, Rajulapati SB, Parcha SR, Kamal MA (2020) Stem cells in tumour microenvironment aid in prolonged survival rate of cancer cells and developed drug resistance: major challenge in osteosarcoma treatment. Curr Drug Metab 21(1):44-52

Braun RK, Chetty C, Balasubramaniam V, Centanni R, Haraldsdottir K, Hematti P, Eldridge MW (2018) Intraperitoneal injection of MSC-derived exosomes prevent experimental bronchopulmonary dysplasia. Biochem Biophys Res Commun 503(4):2653-2658

Breining P, Frølund AL, Højen JF, Gunst JD, Staerke NB, Saedder E, Cases-Thomas M, Little P, Nielsen LP, Søgaard OS (2021) Camostat mesylate against SARS-CoV-2 and COVID-19-rationale, dosing and safety. Basic Clin Pharmacol Toxicol 128(2):204-212

Bustos ML, Huleihel L, Meyer EM, Donnenberg AD, Donnenberg VS, Sciurba JD, Mroz L, McVerry BJ, Ellis BM, Kaminski N (2013) Activation of human mesenchymal stem cells impacts their therapeutic abilities in lung injury by increasing interleukin (IL)-10 and IL-1RN levels. Stem Cells Transl Med 2(11):884-895

Cahill EF, Kennelly H, Carty F, Mahon BP, English K (2016) Hepatocyte growth factor is required for mesenchymal stromal cell protection against bleomycin-induced pulmonary fibrosis. Stem Cells Transl Med 5(10):1307-1318

Chen J-Y, An R, Liu Z-J, Wang J-J, Chen S-Z, Hong M-M, Liu J-H, Xiao M-Y, Chen Y-F (2014) Therapeutic effects of mesenchymal stem cell-derived microvesicles on pulmonary arterial hypertension in rats. Acta Pharmacol Sin 35(9):1121-1128

Chen W, Huang Y, Han J, Yu L, Li Y, Lu Z, Li H, Liu Z, Shi C, Duan F (2016) Immunomodulatory effects of mesenchymal stromal cells-derived exosome. Immunol Res 64(4):831-840

Chen Y-S, Lin E-Y, Chiou T-W, Harn H-J (2020) Exosomes in clinical trial and their production in compliance with good manufacturing practice. Tzu-Chi Med J 32(2):113

Choy K-T, Wong AY-L, Kaewpreedee P, Sia SF, Chen D, Hui KPY, Chu DKW, Chan MCW, Cheung PP-H, Huang X (2020) Remdesivir, lopinavir, emetine, and homoharringtonine inhibit SARS-CoV-2 replication in vitro. Antiviral Res 178:104786

Colao IL, Corteling R, Bracewell D, Wall I (2018) Manufacturing exosomes: a promising therapeutic platform. Trends Mol Med 24(3):242-256

Cortegiani A, Ingoglia G, Ippolito M, Giarratano A, Einav S (2020) A systematic review on the efficacy and safety of chloroquine for the treatment of COVID-19. J Crit Care 57:279-283

Cruz FF, Rocco PRM (2020) The potential of mesenchymal stem cell therapy for chronic lung disease. Expert Rev Respir Med 14(1):31-39

Cruz FF, Borg ZD, Goodwin M, Sokocevic D, Wagner DE, Coffey A, Antunes M, Robinson KL, Mitsialis SA, Kourembanas S (2015) Systemic administration of human bone marrow-derived mesenchymal stromal cell extracellular vesicles ameliorates aspergillus hyphal extract-induced allergic airway inflammation in immunocompetent mice. Stem Cells Transl Med 4(11):1302-1316

de Castro LL, Xisto DG, Kitoko JZ, Cruz FF, Olsen PC, Redondo PAG, Ferreira TPT, Weiss DJ, Martins MA, Morales MM (2017) Human adipose tissue mesenchymal stromal cells and their extracellular vesicles act differentially on lung mechanics and inflammation in experimental allergic asthma. Stem Cell Res Ther 8(1):1-12

De Haan CA, Kuo L, Masters PS, Vennema H, Rottier PJ (1998) Coronavirus particle assembly: primary structure requirements of the membrane protein. J Virol 72(8):6838-6850

Del Fattore A, Luciano R, Pascucci L, Goffredo BM, Giorda E, Scapaticci M, Fierabracci A, Muraca M (2015) Immunoregulatory effects of mesenchymal stem cellderived extracellular vesicles on $\mathrm{T}$ lymphocytes. Cell Transpl 24(12):2615-2627

Devaux CA, Rolain J-M, Raoult D (2020) ACE2 receptor polymorphism: susceptibility to SARS-CoV-2, hypertension, multi-organ failure, and COVID-19 disease outcome. J Microbiol Immunol Infect 53:425

Drela K, Stanaszek L, Nowakowski A, Kuczynska Z, Lukomska B (2019) Experimental strategies of mesenchymal stem cell propagation: adverse events and potential risk of functional changes. Stem Cells Int

Elrashdy F, Aljaddawi AA, Redwan EM, Uversky VN (2020) On the potential role of exosomes in the COVID-19 reinfection/reactivation opportunity. J Biomol Struct Dyn 39:1-12

El-Shennawy L, Hoffmann AD, Dashzeveg NK,Mehl PJ, Yu Z, Tokars VL, Nicolaescu V, Ostiguin C, Jia Y, Li L (2020). Circulating ACE2-expressing exosomes block SARS$\mathrm{CoV}-2$ virus infection as an innate antiviral mechanism. bioRxiv

Epelbaum O (2020) Autopsy findings and venous thromboembolism in patients with COVID-19. Ann Intern Med 173(12):1029-1030

Bian H, Zheng Z-H, Wei D, Zhang Z, Kang W-Z, Hao C-Q, Dong K, Kang W, Xia J-L, Miao J-L (2020). Meplazumab treats COVID-19 pneumonia: an open-labelled, concurrent controlled add-on clinical trial. MedRxiv.

Gao J, Tian Z, Yang X (2020) Breakthrough: chloroquine phosphate has shown apparent efficacy in treatment of COVID-19 associated pneumonia in clinical studies. Biosci Trends

Fujita Y, Kadota T, Araya J, Ochiya T, Kuwano K (2018) Clinical application of mesenchymal stem cell-derived extracellular vesicle-based therapeutics for inflammatory lung diseases. J Clin Med 7(10):355

Galleu A, Riffo-Vasquez Y, Trento C, Lomas C, Dolcetti L, Cheung TS, von Bonin M, Barbieri L, Halai K, Ward S (2017) Apoptosis in mesenchymal stromal cells induces in vivo recipient-mediated immunomodulation. Sci Transl Med 9:416

Ganesan N, Embi N, Hasidah M (2018) The anti-malarial chloroquine modulated cytokine levels and increased animal survivability via Akt-mediated inhibition of GSK3 $\beta$ in burkholderia pseudomallei-infected mice. Trop Biomed 35(3):709-723 
Gao F, Chiu S, Motan D, Zhang Z, Chen L, Ji H, Tse H, Fu Q-L, Lian Q (2016) Mesenchymal stem cells and immunomodulation: current status and future prospects. Cell Death Dis 7(1):e2062-e2062

Gardiner C, Vizio DD, Sahoo S, Théry C, Witwer KW, Wauben M, Hill AF (2016) Techniques used for the isolation and characterization of extracellular vesicles: results of a worldwide survey. J Extracellular Vesic 5(1):32945

Gautret P, Lagier J-C, Parola P, Meddeb L, Mailhe M, Doudier B, Courjon J, Giordanengo V, Vieira VE, Dupont HT (2020) Hydroxychloroquine and azithromycin as a treatment of COVID-19: results of an open-label non-randomized clinical trial. Int $\mathrm{J}$ Antimicrob Agents 56(1): 105949

Gaye B, Fanidi A, Jouven X (2020) Denominator matters in estimating COVID-19 mortality rates. Oxford University Press, Oxford

Gennai S, Monsel A, Hao Q, Park J, Matthay M, Lee J (2015) Microvesicles derived from human mesenchymal stem cells restore alveolar fluid clearance in human lungs rejected for transplantation. Am J Transpl 15(9):2404-2412

Glassberg MK, Minkiewicz J, Toonkel RL, Simonet ES, Rubio GA, DiFede D, Shafazand S, Khan A, Pujol MV, LaRussa VF (2017) Allogeneic human mesenchymal stem cells in patients with idiopathic pulmonary fibrosis via intravenous delivery (AETHER): a phase I safety clinical trial. Chest 151(5):971-981

Gong M, Yu B, Wang J, Wang Y, Liu M, Paul C, Millard RW, Xiao D-S, Ashraf M, Xu M (2017) Mesenchymal stem cells release exosomes that transfer miRNAs to endothelial cells and promote angiogenesis. Oncotarget 8(28):45200

Gu W, Song L, Li X-M, Wang D, Guo X-J, Xu W-G (2015) Mesenchymal stem cells alleviate airway inflammation and emphysema in COPD through down-regulation of cyclooxygenase-2 via p38 and ERK MAPK pathways. Sci Rep 5(1):1-11

Guo D, Zhu X, Pan X (2017) Exosome-potential target for clinical application. Open J Nature Sci 5(1):24-30

Han J, Li Y, Li Y (2019a) Strategies to enhance mesenchymal stem cell-based therapies for acute respiratory distress syndrome. Stem Cells Int. https://doi.org/10.1155/2019/ 5432134

Han J, Liu Y, Liu H, Li Y (2019b) Genetically modified mesenchymal stem cell therapy for acute respiratory distress syndrome. Stem Cell Res Ther 10(1):1-9

Harrell CR, Sadikot R, Pascual J, Fellabaum C, Jankovic MG, Jovicic N, Djonov V, Arsenijevic N, Volarevic V (2019) Mesenchymal stem cell-based therapy of inflammatory lung diseases: current understanding and future perspectives. Stem Cells Int. https://doi.org/10.1155/2019/ 4236973

Hoffmann M, Kleine-Weber H, Schroeder S, Krüger N, Herrler T, Erichsen S, Schiergens TS, Herrler G, Wu N-H, Nitsche A (2020a) SARS-CoV-2 cell entry depends on ACE2 and TMPRSS 2 and is blocked by a clinically proven protease inhibitor. Cell 181(2):271-280

Hoffmann M, Schroeder S, Kleine-Weber H, Müller MA, Drosten C, Pöhlmann S (2020b) Nafamostat mesylate blocks activation of SARS-CoV-2: new treatment option for COVID-19. Antimicrob Agents Chemother 64(6):e00754-e1720

Hoffmann M, Hofmann-Winkler H, Smith JC, Krüger N, Arora P, Sørensen LK, Søgaard OS, Hasselstrøm JB, Winkler M, Hempel T (2021) Camostat mesylate inhibits SARS-CoV2 activation by TMPRSS2-related proteases and its metabolite GBPA exerts antiviral activity. EBioMedicine 65:103255

Hogan SE, Rodriguez Salazar MP, Cheadle J, Glenn R, Medrano C, Petersen TH, Ilagan RM (2019) Mesenchymal stromal cell-derived exosomes improve mitochondrial health in pulmonary arterial hypertension. Am J Physiol-Lung Cell Mol Physiol 316(5):L723-L737

Huang C, Wang Y, Li X, Ren L, Zhao J, Hu Y, Zhang L, Fan G, $\mathrm{Xu} \mathrm{J}, \mathrm{Gu}$ X (2020) Clinical features of patients infected with 2019 novel coronavirus in Wuhan, China. Lancet 395(10223):497-506

Iaccarino G, Grassi G, Borghi C, Ferri C, Salvetti M, Volpe M (2020) Age and multimorbidity predict death among COVID-19 patients: results of the SARS-RAS study of the Italian Society of Hypertension. Hypertension 76(2):366-372

Islam D, Huang Y, Fanelli V, Delsedime L, Wu S, Khang J, Han B, Grassi A, Li M, Xu Y (2019) Identification and modulation of microenvironment is crucial for effective mesenchymal stromal cell therapy in acute lung injury. Am J Respir Crit Care Med 199(10):1214-1224

Jafari D, Malih S, Eslami SS, Jafari R, Darzi L, Tarighi P, Samadikuchaksaraei A (2019) The relationship between molecular content of mesenchymal stem cells derived exosomes and their potentials: opening the way for exosomes based therapeutics. Biochimie 165:76-89

Jafarinia M, Alsahebfosoul F, Salehi H, Eskandari N, Ganjalikhani-Hakemi M (2020) Mesenchymal stem cell-derived extracellular vesicles: a novel cell-free therapy. Immunol Invest 49(7):758-780

Jamshidi E, Babajani A, Soltani P, Niknejad H (2021) Proposed mechanisms of targeting COVID-19 by delivering mesenchymal stem cells and their exosomes to damaged organs. Stem Cell Rev Rep 17:1-17

Jin W, Liang X, Brooks A, Futrega K, Liu X, Doran MR, Simpson MJ, Roberts MS, Wang H (2018) Modelling of the SDF-1/CXCR4 regulated in vivo homing of therapeutic mesenchymal stem/stromal cells in mice. PeerJ 6:e6072

Joo HS, Suh JH, Lee HJ, Bang ES, Lee JM (2020) Current knowledge and future perspectives on mesenchymal stem cell-derived exosomes as a new therapeutic agent. Int J Mol Sci 21(3):727

Jung HE, Kim TH, Lee HK (2020) Contribution of dendritic cells in protective immunity against respiratory syncytial virus infection. Viruses 12(1):102

Kabat M, Bobkov I, Kumar S, Grumet M (2020) Trends in mesenchymal stem cell clinical trials 2004-2018: is efficacy optimal in a narrow dose range? Stem Cells Transl Med 9(1):17-27

Kang CK, Seong M-W, Choi S-J, Kim TS, Choe PG, Song SH, Kim N-J, Park WB, Oh M-D (2020) In vitro activity of lopinavir/ritonavir and hydroxychloroquine against severe acute respiratory syndrome coronavirus 2 at concentrations achievable by usual doses. Korean J Intern Med 35(4):728 
Khatri M, Richardson LA, Meulia T (2018) Mesenchymal stem cell-derived extracellular vesicles attenuate influenza virus-induced acute lung injury in a pig model. Stem Cell Res Ther 9(1):1-13

Kim M, Yun H-W, Choi BH, Min B-H (2018) Three-dimensional spheroid culture increases exosome secretion from mesenchymal stem cells. Tissue Eng Regener Med 15(4):427-436

Kim H, Lee MJ, Bae E-H, Ryu JS, Kaur G, Kim HJ, Kim JY, Barreda H, Jung SY, Choi JM (2020) Comprehensive molecular profiles of functionally effective MSC-derived extracellular vesicles in immunomodulation. Mol Ther 28(7):1628-1644

Kowal J, Arras G, Colombo M, Jouve M, Morath JP, PrimdalBengtson B, Dingli F, Loew D, Tkach M, Théry C (2016) Proteomic comparison defines novel markers to characterize heterogeneous populations of extracellular vesicle subtypes. Proc Natl Acad Sci 113(8):E968-E977

Laffey JG, Matthay MA (2017) Fifty years of research in ARDS. Cell-based therapy for acute respiratory distress syndrome. Biology and potential therapeutic value. Am J Respir Crit Care Med 196(3):266-273

Le Blanc K, Mougiakakos D (2012) Multipotent mesenchymal stromal cells and the innate immune system. Nat Rev Immunol 12(5):383-396

Lee K-Y (2017) Pneumonia, acute respiratory distress syndrome, and early immune-modulator therapy. Int J Mol Sci 18(2):388

Lee C, Mitsialis SA, Aslam M, Vitali SH, Vergadi E, Konstantinou G, Sdrimas K, Fernandez-Gonzalez A, Kourembanas S (2012) Exosomes mediate the cytoprotective action of mesenchymal stromal cells on hypoxiainduced pulmonary hypertension. Circulation 126(22):2601-2611

Leeming D, Genovese F, Sand J, Rasmussen D, Christiansen C, Jenkins G, Maher T, Vestbo J, Karsdal M (2021) Can biomarkers of extracellular matrix remodelling and wound healing be used to identify high risk patients infected with SARS-CoV-2?: lessons learned from pulmonary fibrosis. Respir Res 22(1):1-7

Lei Z-N, Wu Z-X, Dong S, Yang D-H, Zhang L, Ke Z, Zou C, Chen Z-S (2020) Chloroquine and hydroxychloroquine in the treatment of malaria and repurposing in treating COVID-19. Pharmacol Therap 15:107672

Leng Z, Zhu R, Hou W, Feng Y, Yang Y, Han Q, Shan G, Meng F, Du D, Wang S (2020) Transplantation of ACE2-mesenchymal stem cells improves the outcome of patients with COVID-19 pneumonia. Aging Dis 11(2):216

Liao L, Shi B, Chang H, Su X, Zhang L, Bi C, Shuai Y, Du X, Deng Z, Jin Y (2017) Heparin improves BMSC cell therapy: anticoagulant treatment by heparin improves the safety and therapeutic effect of bone marrow-derived mesenchymal stem cell cytotherapy. Theranostics 7(1):106

Lopes-Pacheco M, Robba C, Rocco PRM, Pelosi P (2020) Current understanding of the therapeutic benefits of mesenchymal stem cells in acute respiratory distress syndrome. Cell Biol Toxicol 36(1):83-102

Lou G, Song X, Yang F, Wu S, Wang J, Chen Z, Liu Y (2015) Exosomes derived from miR-122-modified adipose tissuederived MSCs increase chemosensitivity of hepatocellular carcinoma. J Hematol Oncol 8(1):1-11
Lukomska B, Stanaszek L, Zuba-Surma E, Legosz P, Sarzynska S, Drela K (2019) Challenges and controversies in human mesenchymal stem cell therapy. Stem Cells Int. https://doi. org/10.1155/2019/9628536

Lythgoe MP, Middleton P (2020) Ongoing clinical trials for the management of the COVID-19 pandemic. Trends Pharmacol Sci 41(6):363-382

Mancia G, Rea F, Ludergnani M, Apolone G, Corrao G (2020) Renin-angiotensin-aldosterone system blockers and the risk of Covid-19. N Engl J Med 382(25):2431-2440

Mazini L, Rochette L, Amine M, Malka G (2019) Regenerative capacity of adipose derived stem cells (ADSCs), comparison with mesenchymal stem cells (MSCs). Int J Mol Sci 20(10): 2523

McIntosh K, Hirsch MS, Bloom A (2020) Coronavirus disease 2019 (COVID-19). UpToDate Hirsch MS Bloom 5(1):873

Mehta P, McAuley DF, Brown M, Sanchez E, Tattersall RS, Manson JJ (2020) COVID-19: consider cytokine storm syndromes and immunosuppression. Lancet 395(10229):1033-1034

Mei SH, McCarter SD, Deng Y, Parker CH, Liles WC, Stewart DJ (2007) Prevention of LPS-induced acute lung injury in mice by mesenchymal stem cells overexpressing angiopoietin 1. PLoS Med 4(9):e269

Modani S, Tomar D, Tangirala S, Sriram A, Mehra NK, Kumar R, Khatri DK, Singh PK (2021) An updated review on exosomes: biosynthesis to clinical applications. J Drug Target. https://doi.org/10.1080/1061186X.2021.1894436

Mohanty A, Polisetti N, Vemuganti GK (2020) Immunomodulatory properties of bone marrow mesenchymal stem cells. J Biosci 45(1):1-17

Monsel A, Zhu Y-G, Gennai S, Hao Q, Hu S, Rouby J-J, Rosenzwajg M, Matthay MA, Lee JW (2015) Therapeutic effects of human mesenchymal stem cell-derived microvesicles in severe pneumonia in mice. Am J Respir Crit Care Med 192(3):324-336

Moore JB, June CH (2020) Cytokine release syndrome in severe COVID-19. Science 368(6490):473-474

Morrison TJ, Jackson MV, Cunningham EK, Kissenpfennig A, McAuley DF, O'Kane CM, Krasnodembskaya AD (2017) Mesenchymal stromal cells modulate macrophages in clinically relevant lung injury models by extracellular vesicle mitochondrial transfer. Am J Respir Crit Care Med 196(10):1275-1286

Muraca M, Piccoli M, Franzin C, Tolomeo AM, Jurga M, Pozzobon M, Perilongo G (2017) Diverging concepts and novel perspectives in regenerative medicine. Int J Mol Sci 18(5): 1021

Németh K, Leelahavanichkul A, Yuen PS, Mayer B, Parmelee A, Doi K, Robey PG, Leelahavanichkul K, Koller BH, Brown JM (2009) Bone marrow stromal cells attenuate sepsis via prostaglandin E 2-dependent reprogramming of host macrophages to increase their interleukin-10 production. Nat Med 15(1):42-49

Nielsen T, Kristensen AF, Pedersen S, Christiansen G, Kristensen SR (2018) Investigation of procoagulant activity in extracellular vesicles isolated by differential ultracentrifugation. J Extracellular Vesic 7(1):1454777

Nirk EL, Reggiori F, Mauthe M (2020) Hydroxychloroquine in rheumatic autoimmune disorders and beyond. EMBO Mol Med 12(8):e12476 
Nutho B, Mahalapbutr P, Hengphasatporn K, Pattaranggoon NC, Simanon N, Shigeta Y, Hannongbua S, Rungrotmongkol T (2020) Why are lopinavir and ritonavir effective against the newly emerged coronavirus 2019? Atomistic insights into the inhibitory mechanisms. Biochemistry 59(18):1769-1779

Oliphant S, Lines JL, Hollifield ML, Garvy BA (2015) Regulatory $\mathrm{T}$ cells are critical for clearing influenza $\mathrm{A}$ virus in neonatal mice. Viral Immunol 28(10):580-589

Pachler K, Ketterl N, Desgeorges A, Dunai ZA, Laner-Plamberger S, Streif D, Strunk D, Rohde E, Gimona M (2017) $\mathrm{An}$ in vitro potency assay for monitoring the immunomodulatory potential of stromal cell-derived extracellular vesicles. Int J Mol Sci 18(7):1413

Park J, Kim S, Lim H, Liu A, Hu S, Lee J, Zhuo H, Hao Q, Matthay MA, Lee J-W (2019) Therapeutic effects of human mesenchymal stem cell microvesicles in an ex vivo perfused human lung injured with severe $E$. coli pneumonia. Thorax 74(1):43-50

Patel TK, Patel PB, Barvaliya M, Saurabh MK, Bhalla HL, Khosla PP (2021) Efficacy and safety of Lopinavir-Ritonavir in COVID-19: a systematic review of randomized controlled trials. J Infect Public Health 14(6):740-748

Pegtel DM, Gould SJ (2019) Exosomes. Annu Rev Biochem 88:487-514

Phelps J, Sanati-Nezhad A, Ungrin M, Duncan NA, Sen A (2018) Bioprocessing of mesenchymal stem cells and their derivatives: toward cell-free therapeutics. Stem Cells Int. https://doi.org/10.1155/2018/9415367

Phinney DG, Pittenger MF (2017) Concise review: MSCderived exosomes for cell-free therapy. Stem Cells 35(4):851-858

Phinney DG, Di Giuseppe M, Njah J, Sala E, Shiva S, St Croix CM, Stolz DB, Watkins SC, Di YP, Leikauf GD (2015) Mesenchymal stem cells use extracellular vesicles to outsource mitophagy and shuttle microRNAs. Nat Commun 6(1): $1-15$

Popowski KD, Dinh PUC, George A, Lutz H, Cheng K (2021) Exosome therapeutics for COVID-19 and respiratory viruses. View 2:20200186

Qu Z, Lou Q, Cooper DK, Pu Z, Lu Y, Chen J, Ni Y, Zhan Y, Chen J, Li Z (2021) Potential roles of mesenchymal stromal cells in islet allo-and xenotransplantation for type 1 diabetes mellitus. Xenotransplantation 12:e12678

Rao L, Xia S, Xu W, Tian R, Yu G, Gu C, Pan P, Meng Q-F, Cai $\mathrm{X}, \mathrm{Qu}$ D (2020) Decoy nanoparticles protect against COVID-19 by concurrently adsorbing viruses and inflammatory cytokines. Proc Natl Acad Sci 117(44):27141-27147

Rodriguez A-M, Nakhle J, Griessinger E, Vignais M-L (2018) Intercellular mitochondria trafficking highlighting the dual role of mesenchymal stem cells as both sensors and rescuers of tissue injury. Cell Cycle 17(6):712-721

Saeedi P, Halabian R, Fooladi AAI (2019) A revealing review of mesenchymal stem cells therapy, clinical perspectives and Modification strategies. Stem Cell Investig 6:1

Sahin A-R, Erdogan A, Agaoglu P-M, Dineri Y, Cakirci A-Y, Senel M-E, Okyay R-A, Tasdogan A-M (2020) 2019 novel coronavirus (COVID-19) outbreak: a review of the current literature. EJMO 4(1):1-7
Sengupta V, Sengupta S, Lazo A, Woods P, Nolan A, Bremer N (2020) Exosomes derived from bone marrow mesenchymal stem cells as treatment for severe COVID-19. Stem Cells Dev 29(12):747-754

Shah TG, Predescu D, Predescu S (2019) Mesenchymal stem cells-derived extracellular vesicles in acute respiratory distress syndrome: a review of current literature and potential future treatment options. Clin Transl Med 8(1):1-6

Silachev DN, Goryunov KV, Shpilyuk MA, Beznoschenko OS, Morozova NY, Kraevaya EE, Popkov VA, Pevzner IB, Zorova LD, Evtushenko EA (2019) Effect of MSCs and MSC-derived extracellular vesicles on human blood coagulation. Cells 8(3):258

Singhal T (2020) A review of coronavirus disease-2019 (COVID-19). Indian J Pediatr 87(4):281-286

Slabáková E, Culig Z, Remšík J, Souček K (2017) Alternative mechanisms of miR-34a regulation in cancer. Cell Death Dis 8(10):e3100-e3100

Smith T, Bushek J, LeClaire A, Prosser T (2020) COVID-19 drug therapy. Elsevier

Song Y, Dou H, Li X, Zhao X, Li Y, Liu D, Ji J, Liu F, Ding L, $\mathrm{Ni}$ Y (2017) Exosomal miR-146a contributes to the enhanced therapeutic efficacy of interleukin-1 $\beta$-primed mesenchymal stem cells against sepsis. Stem Cells 35(5):1208-1221

Taghavi-Farahabadi M, Mahmoudi M, Soudi S, Hashemi SM (2020) Hypothesis for the management and treatment of the COVID-19-induced acute respiratory distress syndrome and lung injury using mesenchymal stem cellderived exosomes. Med Hypotheses 144:109865

Takeuchi O, Akira S (2009) Innate immunity to virus infection. Immunol Rev 227(1):75-86

Tkach M, Kowal J, Théry C (2018) Why the need and how to approach the functional diversity of extracellular vesicles. Philos Trans R Soc B 373(1737):20160479

Tomar B, Anders H-J, Desai J, Mulay SR (2020) Neutrophils and neutrophil extracellular traps drive necroinflammation in COVID-19. Cells 9(6):1383

Tripisciano C, Weiss R, Eichhorn T, Spittler A, Heuser T, Fischer MB, Weber V (2017) Different potential of extracellular vesicles to support thrombin generation: contributions of phosphatidylserine, tissue factor, and cellular origin. Sci Rep 7(1):1-11

Ullah M, Liu DD, Thakor AS (2019) Mesenchymal stromal cell homing: mechanisms and strategies for improvement. Iscience 15:421-438

van Haaften T, Byrne R, Bonnet S, Rochefort GY, Akabutu J, Bouchentouf M, Rey-Parra GJ, Galipeau J, Haromy A, Eaton F (2009) Airway delivery of mesenchymal stem cells prevents arrested alveolar growth in neonatal lung injury in rats. Am J Respir Crit Care Med 180(11):1131-1142

Vats D, Mukundan L, Odegaard JI, Zhang L, Smith KL, Morel CR, Greaves DR, Murray PJ, Chawla A (2006) Oxidative metabolism and PGC-1 $\beta$ attenuate macrophage-mediated inflammation. Cell Metab 4(1):13-24

Verma S, Saksena S, Sadri-Ardekani H (2020) ACE2 receptor expression in testes: implications in coronavirus disease 2019 pathogenesis. Biol Reprod 103(3):449-451

Vincent MJ, Bergeron E, Benjannet S, Erickson BR, Rollin PE, Ksiazek TG, Seidah NG, Nichol ST (2005) Chloroquine is 
a potent inhibitor of SARS coronavirus infection and spread. Virol J 2(1):1-10

Von Bahr L, Batsis I, Moll G, Hägg M, Szakos A, Sundberg B, Uzunel M, Ringden O, Le Blanc K (2012) Analysis of tissues following mesenchymal stromal cell therapy in humans indicates limited long-term engraftment and no ectopic tissue formation. Stem Cells 30(7):1575-1578

Wang B, Yao K, Huuskes BM, Shen H-H, Zhuang J, Godson C, Brennan EP, Wilkinson-Berka JL, Wise AF, Ricardo SD (2016) Mesenchymal stem cells deliver exogenous microRNA-let7c via exosomes to attenuate renal fibrosis. Mol Ther 24(7):1290-1301

Watanabe T, Tsuchiya A, Takeuchi S, Nojiri S, Yoshida T, Ogawa M, Itoh M, Takamura M, Suganami T, Ogawa Y (2020) Development of a non-alcoholic steatohepatitis model with rapid accumulation of fibrosis, and its treatment using mesenchymal stem cells and their small extracellular vesicles. Regener Therapy 14:252-261

Wei Z, Tang T, Jiang S (2020) The antiviral mechanisms, effects, safety and adverse effects of chloroquine. Eur Rev Med Pharmacol Sci 24(12):7164-7172

Whitford W, Guterstam P (2019) Exosome manufacturing status. Future Med Chem 11(10):1225-1236

Whitford W, Ludlow JW, Cadwell JJ (2015) Continuous production of exosomes: utilizing the technical advantages of hollow-fiber bioreactor technology. Genet Eng Biotechnol News 35(16):34-34

Willis GR, Kourembanas S, Mitsialis SA (2017) Toward exosome-based therapeutics: isolation, heterogeneity, and fitfor-purpose potency. Front Cardiovasc Med 4:63

Willis GR, Mitsialis SA, Kourembanas S (2018) "Good things come in small packages": application of exosome-based therapeutics in neonatal lung injury. Pediatr Res 83(1):298-307

Willms E, Cabañas C, Mäger I, Wood MJ, Vader P (2018) Extracellular vesicle heterogeneity: subpopulations, isolation techniques, and diverse functions in cancer progression. Front Immunol 9:738

Wilson JG, Liu KD, Zhuo H, Caballero L, McMillan M, Fang X, Cosgrove K, Vojnik R, Calfee CS, Lee J-W (2015) Mesenchymal stem (stromal) cells for treatment of ARDS: a phase 1 clinical trial. Lancet Respir Med 3(1):24-32

Wu J, Mafham M, Mamas M, Rashid M, Kontopantelis E, Deanfield J, de Belder M, Gale C (2020) Place and underlying cause of death during the COVID19 pandemic: retrospective cohort study of 3.5 million deaths in England and Wales, 2014 to 2020. MedRxiv. https://doi.org/10. $1101 / 2020.08 .12$

Xi Y (2020) Convalescent plasma therapy for COVID-19: a tried-and-true old strategy? Signal Transduct Target Ther $5(1): 1-4$
Xu Z, Shi L, Wang Y, Zhang J, Huang L, Zhang C, Liu S, Zhao P, Liu H, Zhu L (2020) Pathological findings of COVID-19 associated with acute respiratory distress syndrome. Lancet Respir Med 8(4):420-422

Yan Y, Zou Z, Sun Y, Li X, Xu K-F, Wei Y, Jin N, Jiang C (2013) Anti-malaria drug chloroquine is highly effective in treating avian influenza A H5N1 virus infection in an animal model. Cell Res 23(2):300-302

Yao TT, Qian JD, Zhu WY, Wang Y, Wang GQ (2020) A systematic review of lopinavir therapy for SARS coronavirus and MERS coronavirus-a possible reference for coronavirus disease-19 treatment option. J Med Virol 92(6):556-563

Ye Q, Wang B, Mao J (2020) Cytokine storm in COVID-19 and treatment. J Infect 80(6):607-613

Zhang J, Kong X, Jin X, Gao P, Wang M, Yang L (2019) Bone marrow stromal cells transplantation promotes the resolution and recanalization of deep vein thrombosis in rabbits through regulating macrophage infiltration and angiogenesis. J Cell Biochem 120(7):11680-11689

Zhang H, Penninger JM, Li Y, Zhong N, Slutsky AS (2020a) Angiotensin-converting enzyme 2 (ACE2) as a SARSCoV-2 receptor: molecular mechanisms and potential therapeutic target. Intensive Care Med 46(4):586-590

Zhang Q, Honko A, Zhou J, Gong H, Downs SN, Vasquez JH, Fang RH, Gao W, Griffiths A, Zhang L (2020b) Cellular nanosponges inhibit SARS-CoV-2 infectivity. Nano Lett 20(7):5570-5574

Zhang X, Li X, Fang P, Yan D, Qiuzhen Y, Minjuan S, Jiping L, Hui M, Bo L (2020c) Convalescent plasma in the treatment of severe covid-19: a systematic review and meta-analysis. Iran J Public Health 49(11):2022

Zhou Y, Yamamoto Y, Xiao Z, Ochiya T (2019) The immunomodulatory functions of mesenchymal stromal/ stem cells mediated via paracrine activity. J Clin Med 8(7): 1025

Zhou P, Yang X-L, Wang X-G, Hu B, Zhang L, Zhang W, Si H-R, Zhu Y, Li B, Huang C-L (2020) A pneumonia outbreak associated with a new coronavirus of probable bat origin. Nature 579(7798):270-273

Ziegler CG, Allon SJ, Nyquist SK, Mbano IM, Miao VN, Tzouanas CN, Cao Y, Yousif AS, Bals J, Hauser BM (2020) SARS-CoV-2 receptor ACE2 is an interferonstimulated gene in human airway epithelial cells and is detected in specific cell subsets across tissues. Cell 181(5):1016-1035

Publisher's Note Springer Nature remains neutral with regard to jurisdictional claims in published maps and institutional affiliations. 